\title{
NUMERICAL ANALYSIS OF TUNNEL LED LIGHTING MAINTENANCE FACTOR
}

\author{
Mehmet SAIt Cengiz ${ }^{*}$, ÇIĞDem Cengiz ${ }^{2}$ \\ ${ }^{I}$ Dept. of Technical Vocational School, Bitlis Eren University, Bitlis, Turkey \\ ${ }^{2}$ Faculty of Arts and Sciences, Statistics Department, Bitlis Eren University, Bitlis, Turkey \\ *Corresponding author: msaitcengiz@gmail.com \\ (Received: $9^{\text {th }}$ Oct 2018; Accepted: $7^{\text {th }}$ Nov 2018; Published on-line: ${ }^{\text {st }}$ Dec 2018) \\ https://doi.org/10.31436/iiumej.v19i2.1007
}

\begin{abstract}
It is necessary to periodically maintain lighting equipment in accordance with international standards. Contamination of lamps caused by long-term use of lighting equipment will result in loss of Luminous Flux and optical losses. The decrease in lighting performance poses a visual difficulty for drivers and causes accidents. In this study, the total Maintenance Factor is numerically examined by considering the losses of diffuser and lens for LED lamps used in tunnel lighting. The variation of luminaries performance with years considering Maintenance Factors as regards environmental conditions and features of the luminaries is evaluated to demonstrate the importance of tunnel lighting maintenance. Moreover, to show the importance of LED lamps Maintenance Factor, the variation of illumination levels of LED lamps is analysed under different Maintenance Factors. It is observed that enhancing Maintenance Factor would contribute to energy efficiency.
\end{abstract}

ABSTRAK: Penjagaan peralatan cahaya secara berkala mengikut piawai kebangsaan adalah amat penting. Pencemaran lampu disebabkan penggunaan peralatan cahaya pada jangka panjang akan menyebabkan kehilangan kilauan kerdipan lampu dan optik. Pengurangan pencahayaan ini menyebabkan kesukaran pandangan pada pemandu dan menyebabkan kemalangan jiwa. Kajian ini mengkaji tentang jumlah Faktor Penjagaan secara numerik dengan mengambil kira pengurangan difuser dan kanta pada lampu LED yang digunakan dalam terowong pencahayaan. Faktor Penjagaan pada perubahan kilauan berdasarkan tahun mengambil kira keadaan sekeliling dan ciri khas kilauan. Tambahan, ini dinilai bagi menunjukkan kepentingan penjagaan terowong pencahayaan dan kepentingan Faktor Penjagaan Lampu LED. Perubahan pada tahap terang pada lampu LED dikaji dengan mengambil kira Faktor Penjagaan. Peningkatan pada Faktor Penjagaan telah didapati dapat menjimatkan tenaga.

KEY WORDS: Maintenance factor, LED lamps, Luminaries performance, Numerical analysis, and Tunnel lighting.

\section{INTRODUCTION}

Luminaries and operating conditions are the most important parameters in lighting. Environmental factors account for the loss in the efficiency of luminaries, as dirty luminaries have reduced luminous transmittance. In addition, operating time affects the efficiency of lamps. The performance of luminaries decrease over the time; thus, the performance of a lamp for a specified period of time can be specified. The performance of luminaries during a period of time may be improved by maintenance processes such as cleaning the glass of luminaire or replacing of the lamp [1-4]. Moreover, renewal of all luminaries will also 
improve performance. By considering the estimated performance loss at the system design phase, lighting systems would be able supply the minimum required lighting even at the end of the period when it exhibits the lowest performance [5]. Fig. 1 illustrates the tolerance range associated with Maintenance Factor (MF) as regards performance loss.

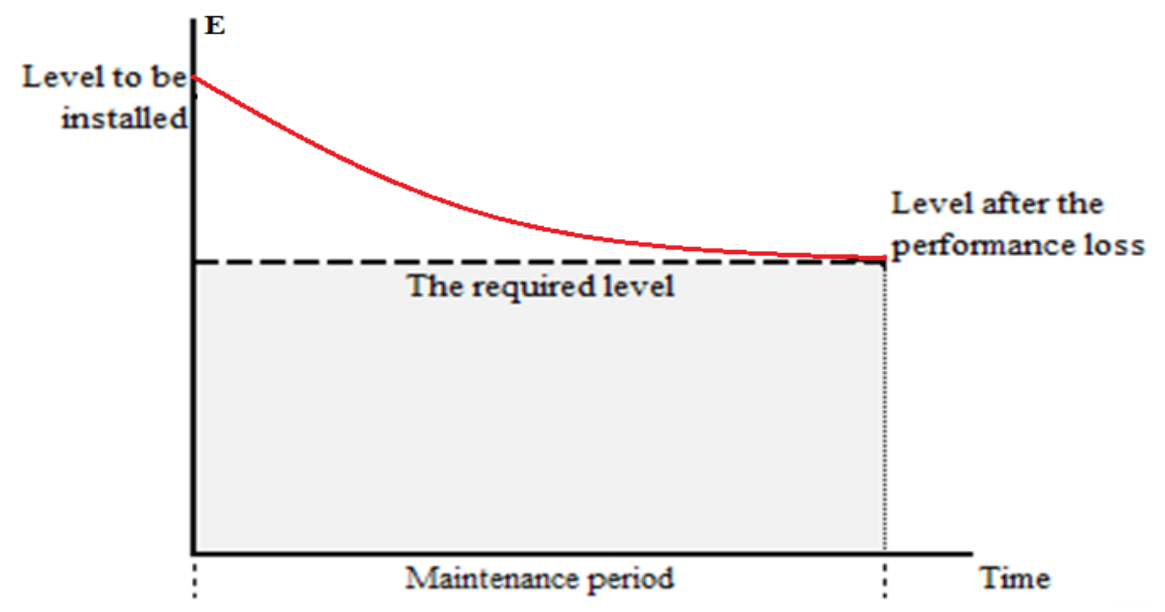

Fig. 1. Tolerance range associated with Maintenance Factor as regards performance loss [5].

Maintenance Factor is a parameter that specifies the performance to be supplied by a lighting system at the end of a certain period depending on the performance at the beginning of the period. Maintenance Factor is described as $80 \%$ for a system for which $20 \%$ of performance loss is estimated at the end of maintenance period. Since MF is used as a multiplier in programs of lighting calculation, lighting levels reached by lighting calculations display the values at the end of a certain period [7-13]. Maintenance Factor varies with the technology level of luminaries. According to CIE 154:2003, the MF of luminaries is formed by the product of multiple indicators of performance [6]. It depends on the protection degrees of the luminaries against contamination (IP65: completely dust prof, protect against water jets), sources of light used in luminaries and all effects that can cause decrease in illumination [6].

\section{LUMINOUS FLUX NUMERICAL CALCULATION}

Luminous Flux is the proportion of flux blazing through a lamp that affects the optic. Its unit is lumen, and it represents ability of radiation to stimulate a sense of radiance. Furthermore, total Luminous Flux is described as the sum of Luminous Fluxes arising from a source and spreading over various parts of the space. The total Luminous Flux falling within a unit surface is defined as the illumination level of that surface, and it is represented by E. Its unit is lux. The radiant power of a lux is equal to a candle light [5]. The Illumination level of a point $\mathrm{P}$ and the geometrical representation of the illumination level of the point is illustrated in Equation 1 and Fig. 2, respectively. Equation 3 demonstrates the relationship between Maintenance Factor and lighting level.

$E_{P}=\sum_{i=1}^{a} \frac{I(C, \gamma)}{h^{2}} \cdot \cos ^{3} \gamma$ 


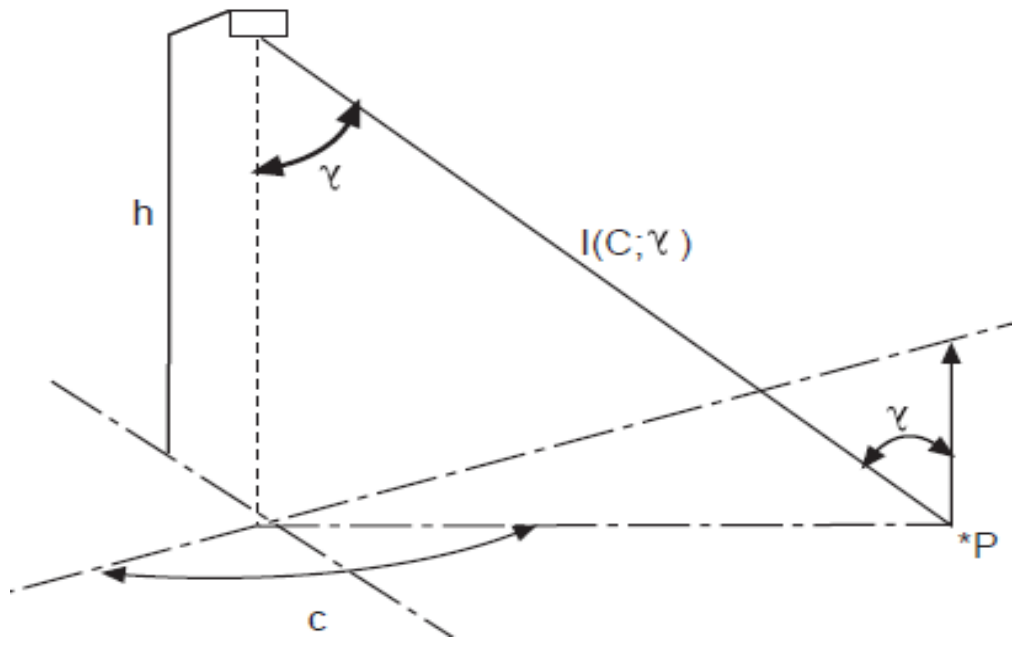

Fig. 2. The tolerance range associated with Maintenance Factor as regards performance loss [5].

Where,

$\mathrm{I}(\mathrm{C}, \gamma)$ : is value of light intensity reaching from luminaire i to point $\mathrm{P}(\mathrm{cd})$, $\gamma$ : is angle of gleam falling within point $\mathrm{P}$ by the vertical line,

a: is the amount of luminaires contributing to point $\mathrm{P}$,

$\mathrm{h}$ : is ground clearance of luminaire photometric center $(\mathrm{m})$

$\mathrm{C}:$ is plane angle.

\section{MAINTENANCE FACTOR}

For luminaires, Maintenance Factor is defined as the proportion of total light coming from a luminaire at the end of the maintenance period in relation to the total light of the luminaire during its primary use. Following the standards associated with the use of MF in lighting, the specifications of lighting equipment in a lighting system are given considering environmental conditions and the Maintenance Factor calculated for a specified maintenance period CIE 154:2003. According to CIE 154:2003, lighting performance should not drop below the minimum levels specified in the standards. Maintenance Factor comprise Lamp Lumen Maintenance Factor (LLMF), lamp survival factor (LSF), and Luminaire Maintenance Factor (LMF). Lamp Lumen Maintenance Factor is the proportion of the Luminous Flux of a lamp at the end of a specified period in relation to the initial Luminous Flux. Lamp Survival Factor is the percentage of lamp survival ratio for Maintenance Factor. Luminaire Maintenance Factor (LMF) is the proportion of Luminous Flux lost at the end of described/specified period as a result of the structural features of luminaires as well as environmental factors. The LMF depends on the protection degree of luminaires against contamination (IP) and environmental pollution. It is specified by the designer according to the contamination condition of the environment during maintenance period or a relevant specification is consulted [5]. Maintenance Factor is calculated according to Equation 2.

$$
\begin{aligned}
& M F=L L M F \times L S F \times L M F \\
& E=\frac{I \cdot \cos ^{3} \varepsilon \cdot \Phi \cdot M F}{h^{2}}
\end{aligned}
$$




\section{TUNEL LED LIGHTING AND MAINTENANCE FACTOR RELATIONSHIP}

In this study, LED lamp luminaires dually inserted $6 \mathrm{~m}$ high used in a tunnel are investigated. The MF for LED lamp luminaires is the product of the three main factors described above. The MF of an LED lamp luminaire with protection degree IP65 is numerically determined. Fig. 3 illustrates a sample of tunnel LED lighting with double suspensions [5].

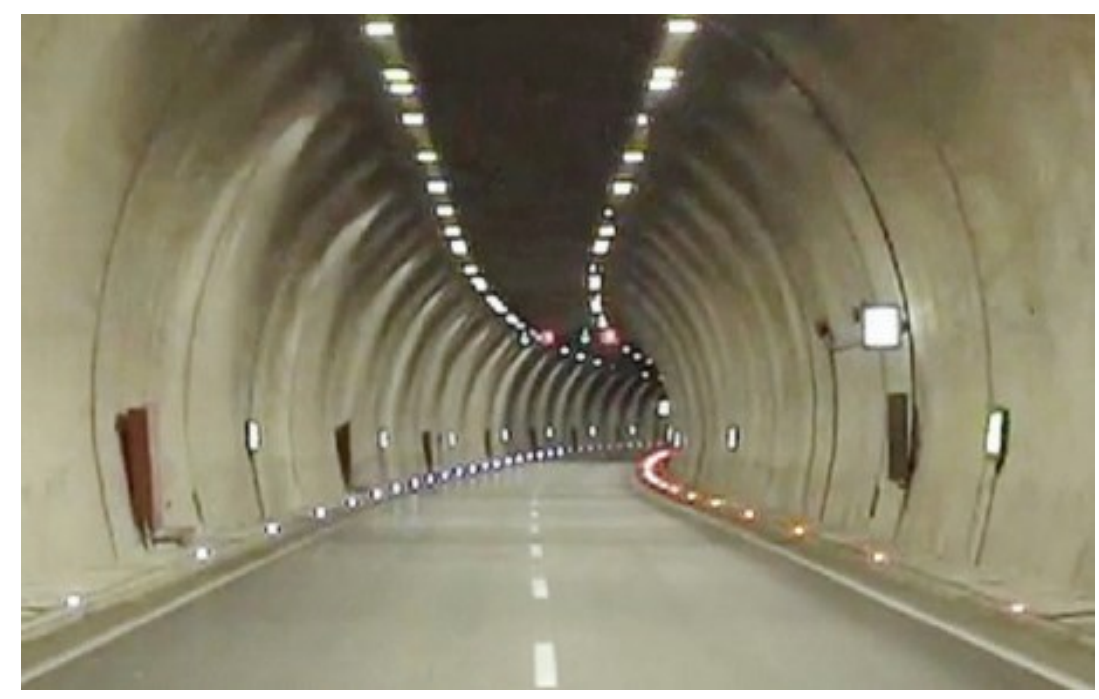

Fig. 3. A sample of tunnel LED lighting with double suspensions.

The time intervals for maintenance (by replacing LED lenses and diffusers) should be specified by the environment pollution level in the site where lighting system will be installed for tunnel lighting. According to the principle of maintenance yearly followed and an environmental condition of high level of pollution, the Luminaire Maintenance Factor (LMF) depending on the contamination of a luminaire with protection degree IP65 is specified as 0.91 in report CIE 154 [6]. Luminaire Maintenance factor according to protection degree of luminaire and the category of environmental pollution is illustrated in Table 1.

Table 1: Luminaire Maintenance Factor according to protection degree of luminaire and the category of environmental pollution is [5]

\begin{tabular}{ccccccc}
\hline \multirow{2}{*}{$\begin{array}{c}\text { Optical Compartment } \begin{array}{c}\text { Exposure time [Years] } \\
\text { IP Rating }\end{array} \\
\text { Pollution } \\
\text { Category }\end{array}$} & \multicolumn{5}{c}{$\mathbf{c}$} \\
\cline { 3 - 8 } IP2X & High & 0.53 & 0.48 & 0.45 & 0.43 & 0.42 \\
& Medium & 0.62 & 0.58 & 0.56 & 0.54 & 0.53 \\
& Low & 0.82 & 0.80 & 0.79 & 0.78 & 0.78 \\
\hline \multirow{2}{*}{ IP5X } & High & 0.89 & 0.87 & 0.84 & 0.80 & 0.76 \\
& Medium & 0.90 & 0.88 & 0.86 & 0.84 & 0.82 \\
& Low & 0.92 & 0.91 & 0.90 & 0.89 & 0.88 \\
\hline \multirow{2}{*}{ IP6X } & High & $\mathbf{0 . 9 1}$ & 0.90 & 0.88 & 0.85 & 0.83 \\
& Medium & 0.92 & 0.92 & 0.89 & 0.88 & 0.87 \\
& Low & 0.93 & 0.93 & 0.91 & 0.90 & 0.90 \\
\hline
\end{tabular}




\subsection{LLMF}

Table 2 illustrates the LLMF of an LED lamp with a service life of 70000 hours.

Table 2: LLMF of LED lamp according to operating time in years

\begin{tabular}{rcc}
\hline Years & Duration of study & LLMF\% \\
\hline $\mathbf{1}$ & 8.766 & 0.980 \\
$\mathbf{2}$ & 17532 & 0.955 \\
$\mathbf{3}$ & 26.298 & 0.930 \\
$\mathbf{4}$ & 35.064 & 0.905 \\
$\mathbf{5}$ & 43.830 & 0.875 \\
$\mathbf{6}$ & 52.596 & 0.845 \\
\hline $\mathbf{7}$ & 61.362 & 0.825 \\
$\mathbf{8}$ & 70.128 & 0.800 \\
\hline
\end{tabular}

Lenses are generally used to direct beams transmitted from LED light sources towards the area to be lighted. Unlike traditional reflector systems, the luminous transmittance of lenses decreases over time. Time-dependent performance criteria of luminaries have been specified by IEC 62722-2-1 and IEC-62717. According to these criteria, confirmation tests of LED modules and LED luminaries were carried out considering 6000 hours maximum [14-16]. Fig. 4 illustrates optical variance caused by use of LED lens at UV/ $65^{\circ} \mathrm{C}$ for 6000 hours.

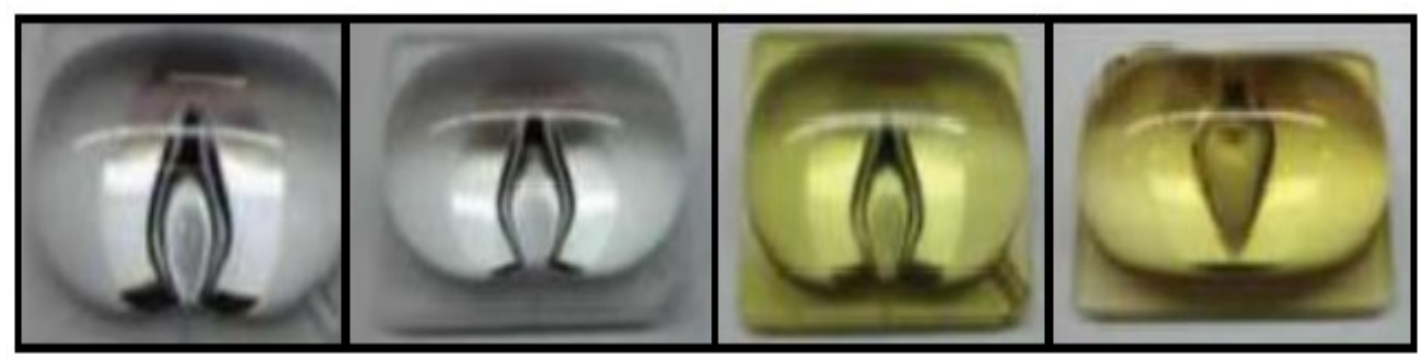

Fig. 4. Optical variance caused by use of LED lens at $\mathrm{UV} / 65^{\circ} \mathrm{C}$ for 6000 hours.

When determining MF in LED luminaries in which lenses are used as a collimator, losses of 5\% should be considered. In this study, it was assumed that lenses were used and that the luminous transmittance of the lenses would change by at least $5 \%$ over the considered time. Table 3 illustrates the total LLMF (\%) of an LED lamp exposed to optical effect.

Table 3: Total LLMF (\%) of an LED lamp exposed to optical effect.

\begin{tabular}{ccccc}
\hline Years & Duration of study & LLMF\% & $\begin{array}{c}\text { Optical } \\
\text { effect \% }\end{array}$ & $\begin{array}{c}\text { Total } \\
\text { LLMF\% }\end{array}$ \\
\hline $\mathbf{1}$ & 8.766 & 98.00 & 5 & 93.00 \\
$\mathbf{2}$ & 17532 & 95.50 & 5 & 90.50 \\
$\mathbf{3}$ & 26.298 & 93.00 & 5 & 88.00 \\
$\mathbf{4}$ & 35.064 & 90.50 & 5 & 85.50 \\
$\mathbf{5}$ & 43.830 & 87.50 & 5 & 82.50 \\
$\mathbf{6}$ & 52.596 & 84.50 & 5 & 79.50 \\
\hline $\mathbf{7}$ & 61.362 & 82.50 & 5 & 77.50 \\
$\mathbf{8}$ & 70.128 & 80.00 & 5 & 75.00 \\
\hline
\end{tabular}


The decrease in Luminous Flux depending on the operating time of lamps was obtained from the catalogue of the producing company [17]. Figure 5 presents the image as obtained from the catalogue. The figure displays the performance loss of LED lamps, which lights the tunnel for 24 hours, depending on operating time. The decrease in Luminous Flux was determined as $7 \%, 9.5 \%, 12 \%, 14.5 \%, 17.5 \%$ and $20.5 \%$ at the end of operating times of 1 , 2, 3, 4, 5 and 6 years, respectively. Fig. 5 displays the decrease in Luminous Flux depending on the operating time of LED lamps.

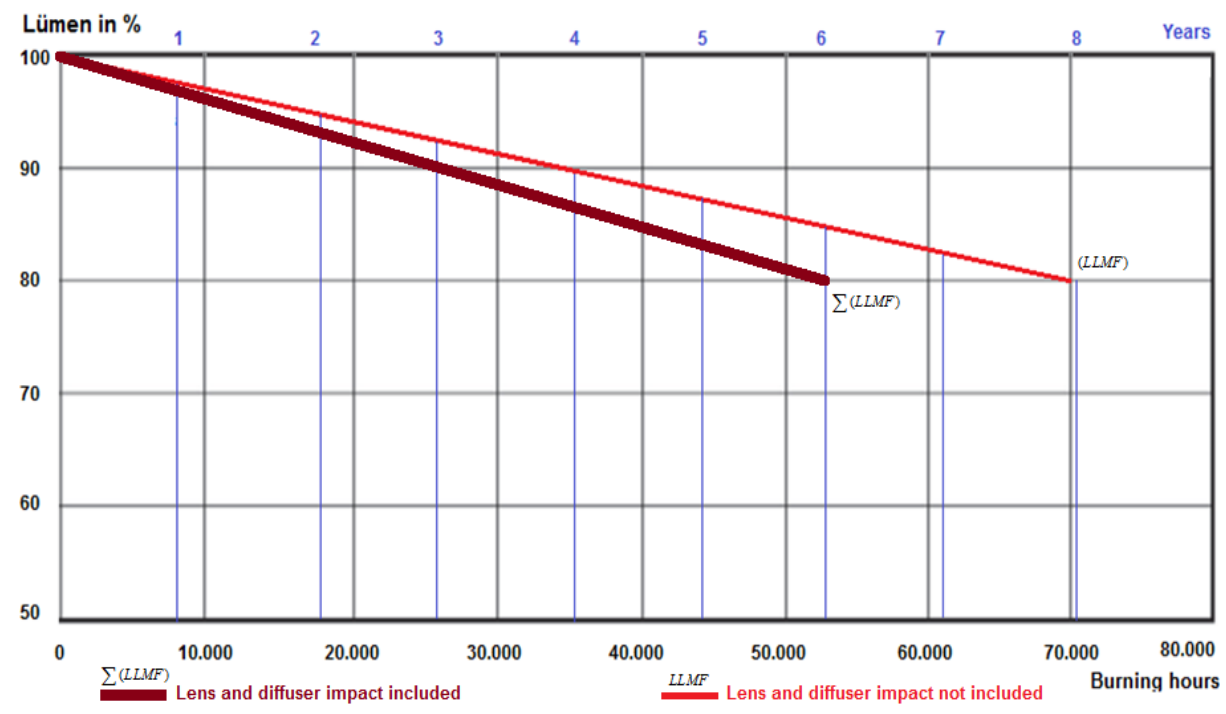

Fig. 5. Decrease in Luminous Flux depending on the operating time of LED lamps.

\subsection{LSF}

In operation strategy, LSF $=1$ is accepted in a case where each attenuated lamp is replaced as early as possible. However, since in general lamping applications, it is not possible to replace broken lamps in a short time, lamps are replaced periodically and collectively. All lamps are replaced in a period of attenuation by $10 \%$ in an area where $10 \%$ is accepted as the maximum ratio of the prescribed attenuation of lamps to replace lamps collectively. Fig. 6 displays the line of LSF for LED lamps.

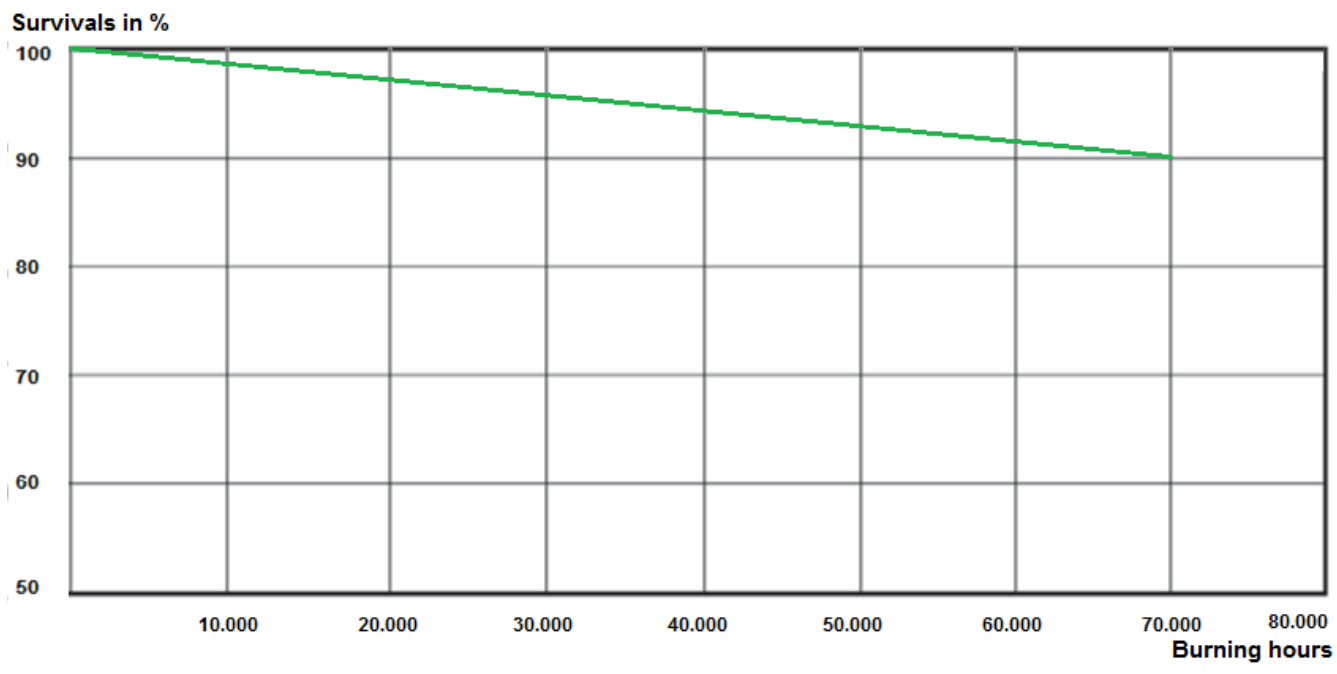

Fig. 6. Line of LSF for LED lamps.

Table 4 illustrates the LSF (\%) of LED lamp according to operating time in years. 
Table 4: LSF (\%) of LED lamp according to operating time in years.

\begin{tabular}{ccc}
\hline Years & Duration of study & LSF\% \\
\hline $\mathbf{1}$ & 8.766 & 98.75 \\
$\mathbf{2}$ & 17532 & 97.50 \\
$\mathbf{3}$ & 26.298 & 96.25 \\
$\mathbf{4}$ & 35.064 & 95.00 \\
$\mathbf{5}$ & 43.830 & 93.75 \\
$\mathbf{6}$ & 52.596 & 92.50 \\
$\mathbf{7}$ & 61.362 & 91.25 \\
$\mathbf{8}$ & 70.128 & 90.00 \\
\hline
\end{tabular}

According to the LSF of the LED lamp, $10 \%$ attenuation rate occurred after eight years. This demonstrates that it is not possible to use the lamp more than eight years. Table 5 illustrates the MF and minimum luminance level required for tunnel lighting with LED lamps.

Table 5: MF and minimum luminance level required for tunnel lighting with LED lamps.

\begin{tabular}{cccccc}
\hline Years & $\begin{array}{c}\text { IP65- High } \\
\text { Pollution LMF }\end{array}$ & LSF & $\begin{array}{c}\text { Total } \\
\text { LLMF }\end{array}$ & $\begin{array}{c}\text { MF } \\
\text { (MF=LMF*LSF*LLMF) }\end{array}$ & E\% \\
\hline $\mathbf{1}$ & 0,91 & 0,9875 & 93 & 0,8357 & 1,1966 \\
$\mathbf{2}$ & 0,91 & 0,975 & 90,5 & 0,803 & 1,2454 \\
$\mathbf{3}$ & 0,91 & 0,9625 & 88 & 0,7708 & 1,2974 \\
$\mathbf{4}$ & 0,91 & 0,95 & 85,5 & 0,7391 & 1,3529 \\
$\mathbf{5}$ & 0,91 & 0,9375 & 82,5 & 0,7038 & 1,4208 \\
$\mathbf{6}$ & 0,91 & 0,925 & 79,5 & 0,6692 & 1,4943 \\
& 0,91 & 0,9125 & 77,5 & 0,6435 & 1,5539 \\
$\mathbf{7}$ & 0,91 & 0,9 & 75 & 0,6143 & 1,628 \\
\hline
\end{tabular}

The LED lamp investigated in this study has a service life of 70000 hours. This period corresponds to an operating time of about eight years. As seen in Figure 4, the LED lamp cannot be used when Luminous Flux decreases by $20 \%$, that is, drops below $80 \%$. The Luminous Flux of the LED lamp would decrease by $20 \%$ after eight years (70000 hours) when LED lens and diffuser effect are neglected. It is seen in Table 2 that the LLMF (\%) of the LED lamp is $80 \%$ in the eight year.

The 5\% loss is formed by time-dependent decrease in the Luminous Flux of the lenses used in directing LED light. When this effect is considered in Table 2, Table 3 is reached. According to Table 3, LLMF is $80 \%$ in the sixth year. In other words, the LED lamp cannot be used after six years because it is indicated in the producer's catalogue that the LED lamp should not be used if LLMF decreases to below $80 \%$. The operating time of the LED lamp decreased from eight years to six years when the effect of optical lens was not considered. 


\subsection{Tunnel Lighting Evaluation}

Fig. 7. illustrates the optic performance change depending on operating for LED luminaires.

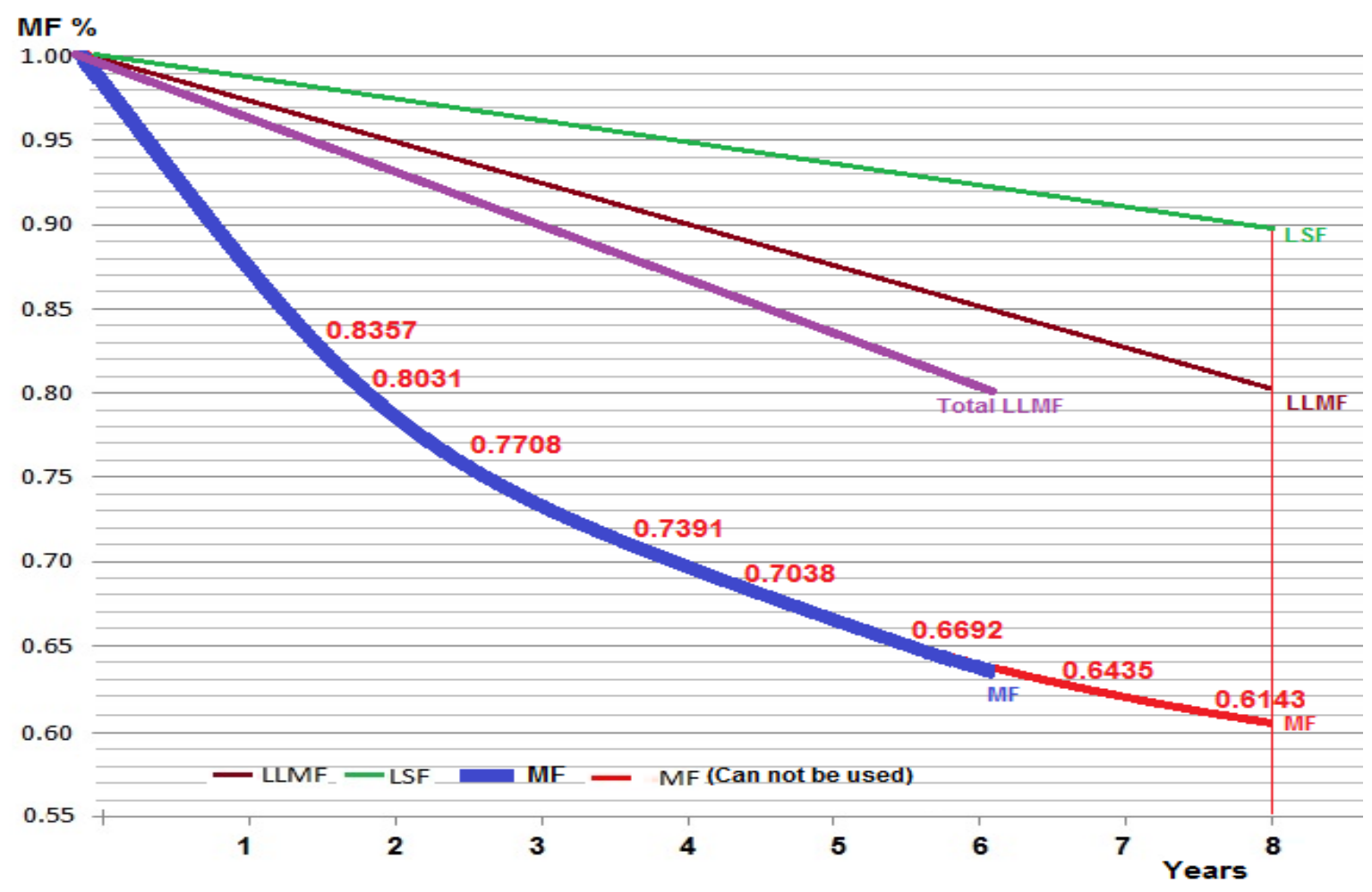

Fig. 7. Optic performance change depending on operating for LED luminaires

According to Figure 7,

- While MF decreases to $83.57 \%$ at the end of the first year, MF increases to $91 \%$ by replacing LED lenses and diffusers

- While MF decreases to $80.30 \%$ at the end of the second year, MF increases to $88 \%$ by replacing LED lenses and diffusers.

- While MF decreases to $77.08 \%$ at the end of the third year, MF increases to $83 \%$ by replacing LED lenses and diffusers.

- At the end of the sixth year, MF decreases to $66.92 \%$. This indicates that all lamps should be replaced as cleaning the luminaire glasses is not sufficient. All lamps were changed since the decrease in illumination level cannot be tolerated as a result of the decrease in Luminous Flux at the end of the sixth MF year.

According to these results, the following comments can be made:

Considering that the LED lenses and diffusers for this lighting system will be replaced every six years and all the lamps will be replaced in the sixth year, to realize an illumination level of $100 \%$ at the end of the six-year period, an initial illumination level of additional $49.43 \%$ is required $(1 / 0.6692=1.4943)$.

The illumination level in interior zone of the tunnel is required to be 149.43 rather than 100 since the illumination level of the LED lamps will decrease from $149.43 \%$ to $100 \%$ at the end of the six-year period. If the tolerance margin of $49.43 \%$ is not allowed, then 
illumination deficiencies can cause accidents as they can adversely affect the visual condition in the tunnel.

\section{CONCLUSION}

It is seen in this study that an LED lamp for tunnel lighting may have a service life lasting for 70000 hours. When examining the usage features of the LED lamps used in the tunnel, it is seen that the LSF and LLMF are $90 \%$ and $80 \%$ in the eighth year, respectively. Moreover, $80 \%$ was reached at the end of the sixth year when optical LED lens and diffuser effects are considered in the LLMF. The conditions related to the use of LED lamps in the tunnel were determined by LLMF, which considers the lens and diffuser effects Since the LLMF decreased to below $80 \%$ at the beginning of the seventh year, the visual conditions in the tunnel will deteriorate at the seventh year, which may result to accidents. The MF at the end of the sixth year was calculated as $66.92 \%$ according to conditions. The total Luminous Flux (E\%) is required to be higher by $49.43 \%$, according to the lowest MF formed at the end of the year.

Efficiency will increase when MF is high. In addition, LED lamps are not required to be replaced frequently and LED lamps can be used for up to six years.

\section{REFERENCES}

[1] Cengiz, MS. Mamiş MS. (2015) Price-efficiency relationship for photovoltaic systems on a global basis, International J. Photoenergy, (2015):1-12.

[2] Arı D, Çıbuk M. Ağgün, F. (2017) Effect of relay-priority mechanism on multi-hop wireless sensor networks, Bitlis Eren University J. Science and Technology, 7(2):145-153, 2017.

[3] Cengiz MS, Mamiş, MS, Kaynakl1, M. (2017) The Temperature-Pressure-Frequency Relationship Between Electrical Power Generating in Stirling Engines, International J. Engineering Research and Development, 9(2):59-64.

[4] Cengiz MS, Mamiş MS, Yurci Y. (2018) Providing electrical power increase by stimulating temperature difference at low temperatures in Stirling motors, Sigma J. Engineering and Natural Sciences, 36(1):86-97.

[5] Cengiz MS, A Simulation and Design Study for Interior Zone Lumınance in Tunnel Lighting, Light Engineering (in press, May-Jun 2019)

[6] CIE Technical Report, CIE-154-2003. (2003) The Maintenance of Outdoor Lighting Systems.

[7] Çıbuk M, Balık HH. (2010) A Novel Communication Application Model for Biomedical Networks, Firat Univ. J. of Enginering, 22 (1):95-109.

[8] Efe, S.B. (2016) Effects of Faults on Power Flow Analysis for Microgrids. 8th International Ege Energy Syposium May 11-13, 2016. 971-976, Afyonkarahisar.

[9] Efe SB, Cebeci M. (2015) Artificial Neural Network Based Power Flow Analysis for Micro Grids. Bitlis Eren University J. Science and Technology, 5(1):42-47.

[10] Cengiz Ç, Kaynaklı M, Gencer G, Eren M, Yapıcı I, Yildirim S, Cengiz MS., Selection Criteria and Economic Analysis of LEDs, Book of Abstracts. Imeset Int. Conf. Mult. Sci. Eng. Tech., October 27-29, 2017, Bitlis, Turkey.

[11] Eren, M., Kaynaklı, M., Yapıcı, I., Gencer, G., Yurci, Y., Cengiz, Ç. Numerical Analysis of Maintanance Factor for Tunnel and Road In Solid State Lighting", International Conference on Multidisciplinary, Science, Engineering and Technology, October 27-29, 2017. Bitlis.

[12] Yıldırım S, Yapıcı I, Atiç S, Eren M, Palta O, Cengiz Ç, Cengiz MS., Yurci Y, Numerical Analysis of Productivity and Redemption Periods in LED Illimunation. Imeset Book of Abstracts, Int. Conf. Mult. Sci. Eng. Tech., 12-14 July 2017, Baku.

[13] Cengiz MS, Eren M, Cengiz Ç, Yıldırım S, Yapıcı İ, Yurci Y, Atiç S, Palta O, Numerical analysis of warming and warming problem in LED lamps. Imeset International Conference Baku Book of Abstracts, 12-14 July 2017. Baku

[14] IEC 62717, (2014) LED module for general lighting. Performance requirements, 2014 
[15] IEC 62722-2-1, (2014) Luminare perforamnce Part 1 General Requirements, 2014

[16] IEC 62722-1, (2014) Luminaire performance-Part 2-1 : Particular requirements for LED luminaries, 2014

[17] Myled Lighting-Revision 2-2018, Available:https://www.myledlightingguide.com/led-streetlight-40w-240w (07/01/2018) 